\title{
Article \\ Object-based land use and land cover change detection in multi temporal remote-sensing images
}

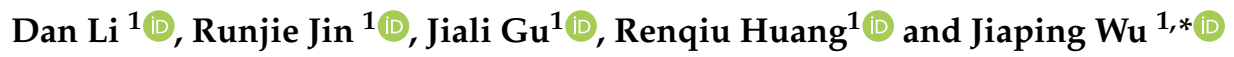 \\ 1 Institute of Islands and Ecosystems,Zhejiang University, Zhoushan, China; Danl@zju.edu.cn \\ * Correspondence: Danl@zju.edu.cn; Tel.: +86-1588-881-1360
}

\begin{abstract}
The changing of land use and land cover (LULC) are both affected by climate and human activity and affect climate, biological diversity, and human well-being. Accurate and timely information about the LULC pattern and change is crucial for land management decision-making, ecosystem monitoring, and urban planning, especially in developing economies undergoing industrialization, urbanization, and globalization. Biodiversity degradation and urban expansion in eastern China are research hot-spots. However, the influence of LULC changes on the region remains largely unexplored. Here, an object-based and multi-temporal image analysis approach was developed to detect how LULC changes during 1985-2015 in the Tiaoxi watershed (Zhejiang province, eastern China) using Landsat TM and OLI data. The main objective of this study is to improve the accuracy of unsupervised change detection from object-based and multi-temporal images. To this end, a total of seven LULC maps are generated with multi-temporal images. A random stratified sample design was used for assessing change detection accuracy. The proposed method achieved an overall accuracy of $91.86 \%, 92.14 \%, 92.00 \%$, and $93.86 \%$ for $2000,2005,2010$, and 2015, respectively. Nevertheless, the proposed method, in conjunction with object-oriented and multi-temporal satellite images, offers a robust and flexible approach to LULC changes mapping that helps with emergency response and government management. Urbanization and agriculture efficiency are the main reasons for LULC changes in the region. We anticipate that this freely available data will improve the modeling for surface forcing, provide evidence of changes in LULC, and inform water-management decision-making.
\end{abstract}

Keywords: Land use and land cover; Classification; Object-based change detection; Multitemporal image analysis; Landsat; Tiaoxi

\section{Introduction}

Land use and land cover (LULC) changes are important ingredients in global environmental change [1]. Land cover is an essential climate variable that impacts numerous environmental processes and patterns ranging from albedo and hence climate to zoogeographic distributions and hence patterns of biodiversity. Such changes are usually caused by human activities (e.g., deforestation, urbanization, agriculture intensification, overgrazing, and subsequent land degradation), however, natural factors can also contribute to these changes [2]. People's responses to economic opportunities, as mediated by institutional factors, drive land-cover changes [3]. The rapid development of the economy requires LULC information for the efficient management of the environment and living conditions. Therefore, the time series of legacy land use maps are needed for the quantification of changes [4]. The phenological information for vegetation derived from multi-seasonal imagery is very useful for mapping tree species [5,6], forest cover $[7,8]$, crop types [9,10], bush encroachment [11], grassland [12], and LULC changes $[13,14]$.

Nowadays, the amount and availability of multi-temporal images are experiencing a fast increase. This is due to the increasing number of space missions, the increases in data temporal resolution, as well as free accessible data policy adopted for missions 
like Landsat and Sentinel. Multi-temporal image analysis (MTIA) becomes more economically viable. Besides, new data analysis paradigms such as deep learning [15-17] are being used to classify and discriminate multi-temporal images. Rather than traditional classifiers such as the maximum likelihood classifier, discriminative classifiers based on k-nearest neighbor (KNN), support vector machine (SVM), extreme learning machine (ELM) and random forest (RF) play important roles in supervised classification. MTIA technology has been prompted to play a key role in the study of LULCs under anthropogenic influences such as urban expansion and deforestation [18].

The traditional change detection method is pixel-based image analysis (PBIA). It detects the occurrence of changes based on the comparison of pixels without consideration of spatial context or membership to real-world objects. Object-based image analysis (OBIA), which operates at the scale of real-world objects rather than pixels, offers a means of analyzing Earth observation (EO) data in a realistic context and integrating associated ancillary information to support real-world applications [19]. Object-based image mapping reduces noise in the original image (i.e., erroneous pixel values, often referred to as the "salt and pepper" effect) to characterize the features of interest effectively [20], and these can exploit landscape features to increase the accuracy and usability of EO-derived products [19]. The advantage of object-based classification is that it groups neighboring pixels into meaningful areas according to their spatial and spectral [21]. According to the most recent studies, OBIA methods have been more effective and reliable than the traditional PBIA methods for image processing [22-26].

China's urbanization process has followed a unique course and transformed the country since the early 1980s. Tremendous LULC changes have occurred in many coastal regions of China such as the Yangtze River Delta region [27] and the Pearl River Delta region [28]. Taihu Lake is the third-largest freshwater lake in China and serves as a drinking water source for 30 million residents. It is also the region with the most rapid economic development and the most intense land-use change. Tiaoxi River is one of the main rivers connected to Taihu lake and contributes $>60 \%$ of the source water [29]. The ecological environment of the Tiaoxi River basin has been seriously disturbed by anthropogenic activities. The region is more representative of the eastern part of China. Research in this region has helped to shed light on the urbanization process in eastern China in recent years, and these experiences are useful for planning and management in underdeveloped areas of central and western China.

Remote sensing (RS) and Geographic Information System (GIS) are two effective tools for detecting and analyzing land cover and its changes over a certain period through integrating spatial and temporal windows of the study area. To determine changes over time, land cover maps for several different years are needed and resultant analysis helps the respective administrator to understand the current landscape along with changing patterns [30]. It also helps to understand and evaluate past management decisions as well as predict possible effects of their current decisions before their implementation [31]. The objective of this research was to utilize GIS and RS applications to find out the extent of changes occurring over the last 30 years in the Tiaoxi watershed, China. Additionally, the specific objectives included: (1) Delineating the watershed of Tiaoxi River; (2) Detecting chronological LULC changes combined with MTLA and OBIA methods in Tiaoxi watershed from 1985 to 2015; (3) Determining shift in LULC categories through spatial comparison of LULC data produced (4) Exploring the potential of combining GIS and RS to study the spatial distribution of different LULCs.

\section{Study area}

The Tiaoxi watershed, ranging from $30^{\circ} 07^{\prime} \mathrm{N}$ to $31^{\circ} 11^{\prime} \mathrm{N}$ latitude and from $119^{\circ}$ $13^{\prime} \mathrm{E}$ to $120^{\circ} 19^{\prime} \mathrm{E}$ longitude, is part of the southern catchment of Taihu Lake, in the northern part of Zhejiang Province, the eastern coast of China (Figure 1). The watershed covers $5,814 \mathrm{~km}^{2}$ and has 2.3 million residents. This region is characterized by a semitropical climate with an average annual temperature of $15.6^{\circ} \mathrm{C}$ and rainfall of 1,460 
$\mathrm{mm}$, respectively. The rainfall is highly seasonal, with $60-70 \%$ falls during spring and summer. The region's topography is slanted downward from southwest to northeast, and the mountain heights decrease from 1,500 meters to merely 3-5 meters above the sea level from southwest to northeast, with an open-pit mine whose elevation is only minus 36 meters above sea level. Forest is the dominant land-use type in the study area of the Tiaoxi watershed, which covers approximately $60 \%$ of the land within the basin. Farmland, orchard, tea garden, surface waters, and urban areas occupy the rest of the watershed [32]. As one of the most active areas in China's economy, the agricultural production structure of this region has gradually changed, and the planting of cash crops has gradually replaced grain crops. In this study, land uses were categorized into the following 6 groups including (1) Forest, (2) Farmland, (3) Garden-plot, (4) Built-up, (5) Water, and (6) Barren, respectively. The forest includes pure bamboo forests, bamboo mixed with Pine, and broad-leaved forest. Farmland mainly consists of rice paddies and some vegetable fields. The garden-plot is dominated by tea plantations, as well as economic shrubs such as blueberry, flowers, and nursery stock. Build-up includes impervious surfaces such as roads, roofs, and other paved surfaces in urban and rural areas. Water area includes rivers, lakes, reservoirs, and aquaculture ponds. Barren land includes exposed soil from abandoned open-pit mines and some undeveloped construction sites.

Starting in 1978, when China adopted its open-door policy, rapid socioeconomic development and population growth occurred in the Tiaoxi watershed. The Gross Domestic Product (GDP) was less than 0.7 billion RMB in 1978 but exceeded 206 billion $\mathrm{RMB}$ in 2015. Remarkably, rapid socioeconomic development and a lack of land planning led to a disorderly and large-scale rural settlement expansion for a long period [33], which exerted significantly negative impacts on soil resources. Given these facts, the Tiaoxi watershed is an atypical example as regards the characterization of the impacts of anthropocentric activities on LULC in modern China. 


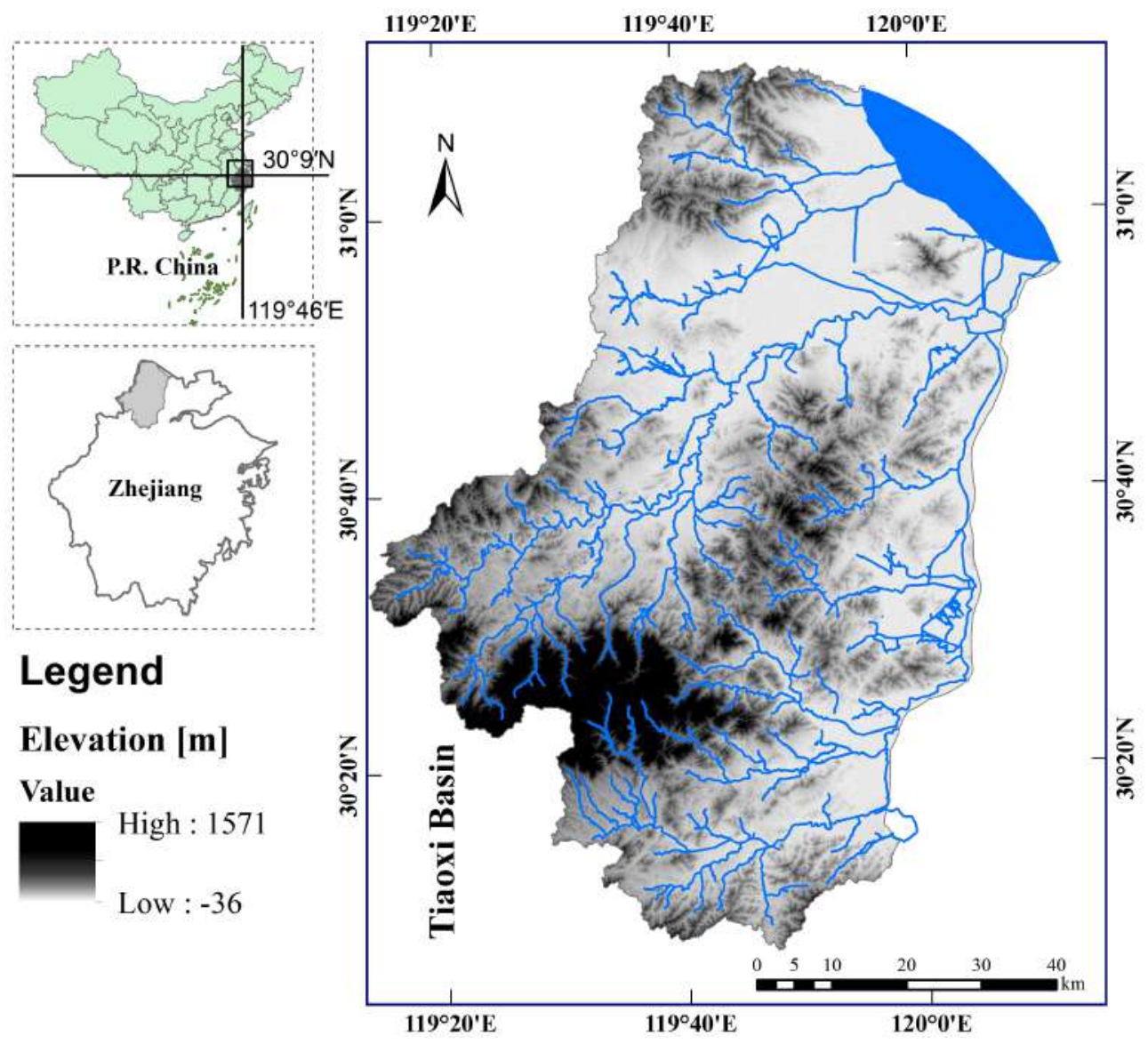

Figure 1. The location of Tiaoxi watershed, Zhejiang, China, DEM, and river lines.

\section{Materials and Methods}

\subsection{Data source}

The period of study in this paper is from 1985 to 2015, and land use data were obtained based on historical Landsat TM and OLI satellite images every season in 1985, $1990,1995,2000,2005,2010$, and 2015. The detail of the satellite images is given below (Table 1). To distinguish the main crops from the tea garden, multi-temporal images were selected, including spring, summer, autumn, and winter [34]. The digital elevation model (DEM) dataset and digital line graph (DLG) were both provided by the Chinese National Bureau of Surveying and Mapping. The spatial resolution of satellite images and DEM are at $30 \times 30 \mathrm{~m}$ resolution. Urban planning and socioeconomic data were used as driving factors of the LULC change detection process. 
Table 1. Different data types used in this study.

\begin{tabular}{|c|c|c|c|}
\hline ID Data type & Source & Resolution & Data cover \\
\hline 1 Landsat $4 \mathrm{TM}$ & USGS & $30 \mathrm{~m}$ & 1989 \\
\hline 2 Landsat $5 \mathrm{TM}$ & USGS & $30 \mathrm{~m}$ & $1985-2010$ \\
\hline 3 Landsat 8 OLI & USGS & $30 \mathrm{~m}$ & 2015 \\
\hline $\begin{array}{l}4 \text { Digital Orthophoto } \\
\text { Map (DOM) }\end{array}$ & $\begin{array}{l}\text { Chinese National Bureau of } \\
\text { Surveying and Mapping }\end{array}$ & $1 \mathrm{~m}$ & $1985-2010$ \\
\hline $\begin{array}{ll}5 & \text { Digital Elevation } \\
& \text { Model (DEM) }\end{array}$ & $\begin{array}{l}\text { Chinese National Bureau of } \\
\text { Surveying and Mapping }\end{array}$ & $30 \mathrm{~m}$ & \\
\hline $6 \begin{array}{l}\text { Digital Line Graph } \\
\text { (DLG) }\end{array}$ & $\begin{array}{l}\text { Chinese National Bureau of } \\
\text { Surveying and Mapping }\end{array}$ & 1:50000 & \\
\hline 7 Zhejiang soil database & Zhejiang University & $1: 50000$ & \\
\hline 8 City Planning & $\begin{array}{l}\text { Hangzhou/Huzhou Plan- } \\
\text { ning Bureau }\end{array}$ & & $2015-2020$ \\
\hline 9 Socioeconomic data & $\begin{array}{l}6 \text { Counties statistical year- } \\
\text { book }\end{array}$ & $\begin{array}{l}\text { every } \\
\text { year }\end{array}$ & 1984-2015 \\
\hline
\end{tabular}

\subsection{Detection indexes}

The Normalized Difference Vegetation Index (NDVI) [35], the Normalized Difference Water Index (NDWI) [34], and the Normalized Difference Built-up Index (NDBI) [36] are the most commonly used indexes for detection vegetation, water, and built-up. The NDVI, MNDWI, and NDBI are expressed as follows:

$$
\begin{gathered}
\text { NDVI }=(\text { Nir }- \text { Red }) /(\text { Nir }+ \text { Red }) \\
M N D W I=(\text { Green }- \text { Mir }) /(\text { Green }+ \text { Mir }) \\
\text { NDBI }=(\text { Mir }- \text { Nir }) /(\text { Mir }+ \text { Nir })
\end{gathered}
$$

Where Green is a green band such as TM band 2 and OLI band 3, Red is a red band such as TM band 3 and OLI band 4, Nir is a near-infrared band such as TM band 4 and OLI band 5, and Mir is a mid-infrared band such as TM band 5 and OLI band 6 .

\subsection{Classification}

This study implemented an object-based rule set that uses multi-temporal remote sensing images, spectral bands, spectral indices, and geometry to characterize agricultural and related LULC in the Tiaoxi watershed. The multi-seasonal remote sensing data set consists of four image dates from a single year. Generally, multi-spectral and seasonal imagery can largely support higher classification accuracy than single-date imagery [37]. The first step of the analysis is to generate homogeneous image objects or segments using the multi-resolution segmentation algorithm (MRSA) with parameters of scale, color, shape, smoothness, and compactness in eCognition (Figure 2). In the results of segmentation, the consistency of gray, the smoothing of the boundary, and the connectivity are fulfilled [38]. Once the image is segmented, the value of the discriminant feature that is going to be thresholded is calculated and stored for each segment as an object variable. Then we move on to classifying the segments. We defined 6 classes of LULC. We use threshold classification methods to identify water, build-up, barren, and forest. Then we use a support vector machine (SVM) classifier to obtain farmland and garden-plot. 


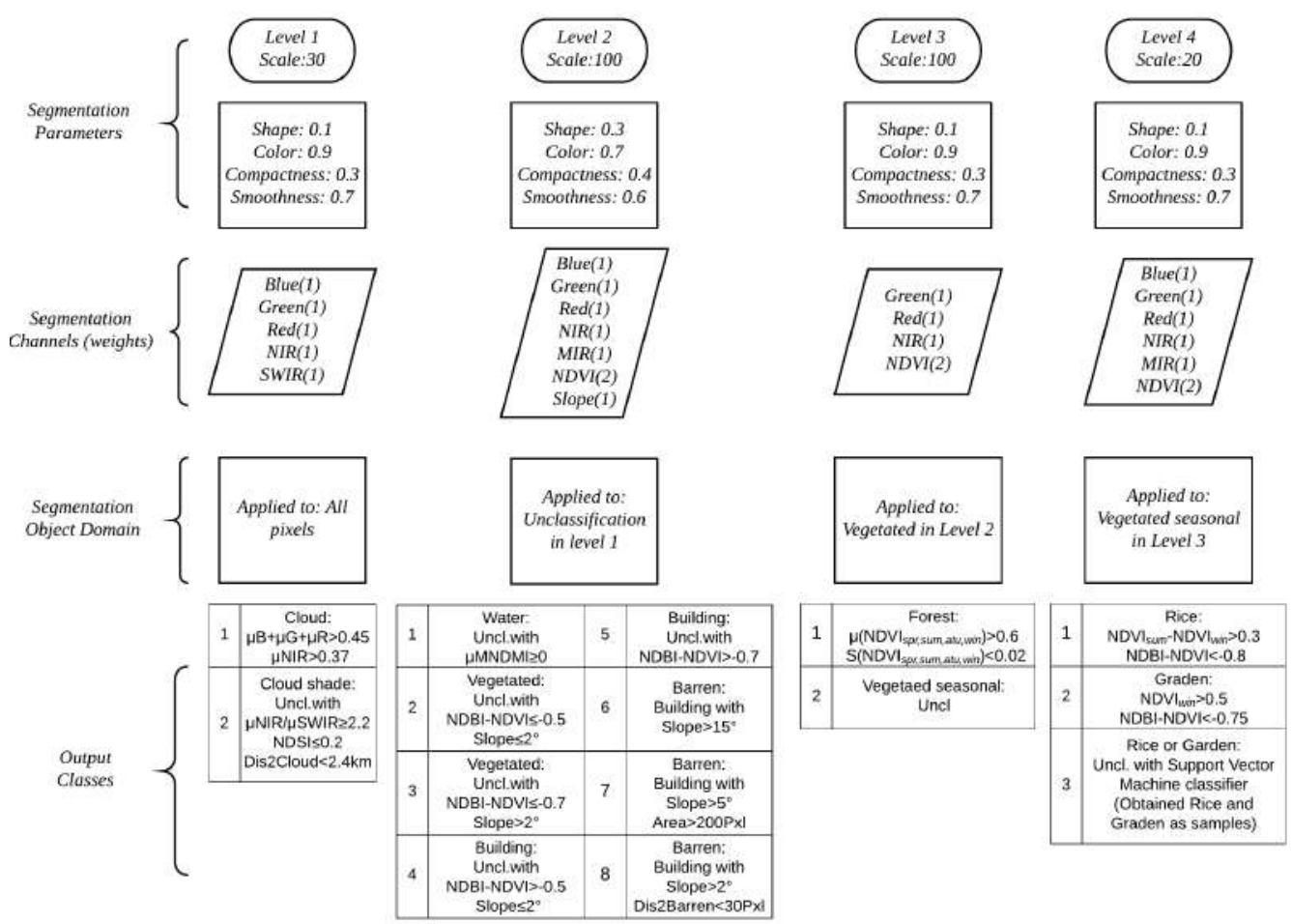

Figure 2. Segmentation parameters and main usage of each level.

\subsection{Accuracy assessment}

To know where and when LULC changes occur, the primary source for reference data is Landsat images themselves [39]. High spatial resolution images from Google Earth and ground-truth data can help manual interpretation of the land cover classes [40]. Their high spatial resolution helps determine LULC changes at longer time intervals. Ground-truth data is used to evaluate how well the classification represents the real world. A random stratified sample design was used for assessing change detection accuracy [41].

\section{Results}

\subsection{Accuracy assessment}

For accuracy assessment, 2800 points were searched randomly from Google Earth and Digital Orthophoto Map for a random point table. From these points, the error matrix was produced to assess errors in the final classification. The summary of the error matrix of the Tiaoxi watershed for the years 2000, 2005, 2010, and 2015 are shown in Table 2, Table 3, Table 4, and Table 5 respectively. Due to the lack of historical data, the accuracy test of the first three periods of land use maps was not performed. The overall accuracy for supervised classification images of 2000, 2005, 2010, and 2015 was found to be $91.86 \%, 92.14 \%, 92.00 \%$, and $93.86 \%$, and Kappa value for those years was $0.9039,0.9071,0.9055$, and 0.9261 respectively. These Kappa values depict that land use classification accuracy is acceptable [42]. 
Table 2. Error matrix showing the accuracy of 2000 supervised land use classification.

\begin{tabular}{|c|c|c|c|c|c|c|c|c|c|}
\hline \multirow[b]{2}{*}{$\begin{array}{l}\text { Classified } \\
\text { Data }\end{array}$} & \multicolumn{6}{|c|}{ Reference Data } & \multirow[b]{2}{*}{ Total } & \multirow{2}{*}{$\begin{array}{l}\text { PA } \\
(\%)\end{array}$} & \multirow{2}{*}{$\begin{array}{l}\text { UA } \\
(\%)\end{array}$} \\
\hline & Barren & Build & Forest & $\begin{array}{l}\text { Garden } \\
\text { plot }\end{array}$ & Far & Water & & & \\
\hline Barren & 92 & 11 & 0 & 5 & 0 & 0 & 108 & 92.0 & 85.2 \\
\hline Build & 4 & 133 & 0 & 2 & 0 & 0 & 139 & 88.7 & 95.7 \\
\hline Forest & 2 & 1 & 139 & 3 & 0 & 4 & 149 & 92.7 & 93.3 \\
\hline Garden plot & 1 & 2 & 10 & 87 & 3 & 1 & 104 & 87.0 & 83.7 \\
\hline Farmland & 0 & 2 & 1 & 3 & 97 & 0 & 103 & 97.0 & 94.2 \\
\hline Water & 1 & 1 & 0 & 0 & 0 & 95 & 97 & 95.0 & 97.9 \\
\hline
\end{tabular}

Table 3. Error matrix showing the accuracy of 2005 supervised land use classification.

\begin{tabular}{|c|c|c|c|c|c|c|c|c|c|}
\hline \multirow[b]{2}{*}{$\begin{array}{l}\text { Classified } \\
\text { Data }\end{array}$} & \multicolumn{6}{|c|}{ Reference Data } & \multirow[b]{2}{*}{ Total } & \multirow{2}{*}{$\begin{array}{l}\text { PA } \\
(\%)\end{array}$} & \multirow{2}{*}{$\begin{array}{l}\text { UA } \\
(\%)\end{array}$} \\
\hline & Barren & Build & Forest & $\begin{array}{l}\text { Garden } \\
\text { plot }\end{array}$ & Far & Water & & & \\
\hline Barren & 93 & 7 & 0 & 5 & 0 & 0 & 105 & 93.0 & 88.6 \\
\hline Build & 5 & 140 & 0 & 2 & 0 & 0 & 147 & 93.3 & 95.2 \\
\hline Forest & 1 & 0 & 139 & 3 & 0 & 2 & 145 & 92.7 & 95.9 \\
\hline Garden plot & 0 & 1 & 10 & 85 & 5 & 2 & 103 & 85.0 & 82.5 \\
\hline Farmland & 0 & 1 & 1 & 5 & 95 & 0 & 102 & 95.0 & 93.1 \\
\hline Water & 1 & 1 & 0 & 0 & 0 & 96 & 98 & 95.0 & 98.0 \\
\hline
\end{tabular}

Table 4. Error matrix showing the accuracy of 2010 supervised land use classification.

\begin{tabular}{|c|c|c|c|c|c|c|c|c|c|}
\hline \multirow[b]{2}{*}{$\begin{array}{l}\text { Classified } \\
\text { Data }\end{array}$} & \multicolumn{6}{|c|}{ Reference Data } & \multirow[b]{2}{*}{ Total } & \multirow{2}{*}{$\begin{array}{l}\text { PA } \\
(\%)\end{array}$} & \multirow{2}{*}{$\begin{array}{l}\text { UA } \\
(\%)\end{array}$} \\
\hline & Barren & Build & Forest & $\begin{array}{l}\text { Garden } \\
\text { plot }\end{array}$ & Far & Water & & & \\
\hline Barren & 90 & 8 & 0 & 3 & 1 & 0 & 102 & 90.0 & 88.2 \\
\hline Build & 4 & 136 & 0 & 1 & 0 & 0 & 141 & 90.7 & 96.5 \\
\hline Forest & 2 & 1 & 135 & 4 & 0 & 2 & 144 & 90.0 & 93.8 \\
\hline Garden plot & 2 & 2 & 13 & 88 & 1 & 1 & 107 & 88.0 & 82.2 \\
\hline Farmland & 1 & 2 & 2 & 4 & 98 & 0 & 102 & 98.0 & 91.6 \\
\hline Water & 1 & 1 & 0 & 0 & 0 & 97 & 99 & 97.0 & 98.0 \\
\hline
\end{tabular}

Table 5. Error matrix showing the accuracy of 2015 supervised land use classification.

\begin{tabular}{|c|c|c|c|c|c|c|c|c|c|}
\hline \multirow[b]{2}{*}{$\begin{array}{l}\text { Classified } \\
\text { Data }\end{array}$} & \multicolumn{6}{|c|}{ Reference Data } & \multirow[b]{2}{*}{ Total } & \multirow{2}{*}{$\begin{array}{l}\text { PA } \\
(\%)\end{array}$} & \multirow{2}{*}{$\begin{array}{l}\text { UA } \\
(\%)\end{array}$} \\
\hline & Barren & Build & Forest & $\begin{array}{l}\text { Garden } \\
\text { plot }\end{array}$ & Far & Water & & & \\
\hline Barren & 93 & 12 & 0 & 1 & 0 & 0 & 106 & 93.0 & 87.7 \\
\hline Build & 3 & 133 & 1 & 1 & 1 & 0 & 139 & 88.7 & 95.7 \\
\hline Forest & 0 & 0 & 142 & 7 & 1 & 0 & 150 & 94.7 & 94.7 \\
\hline Garden plot & 2 & 0 & 4 & 86 & 8 & 1 & 101 & 86.0 & 85.2 \\
\hline Farmland & 1 & 4 & 3 & 3 & 90 & 3 & 104 & 90.0 & 86.5 \\
\hline Water & 1 & 1 & 0 & 2 & 0 & 96 & 100 & 96.0 & 96.0 \\
\hline
\end{tabular}

\subsection{Land use classification and Temporal changes}

It was expected that the results of land use mapping of the Tiaoxi watershed would provide information on (a) distribution of land use categories and (b) identification and estimation of land use changes over the past 30 years. During the field survey, the study 
area's land uses were categorized into the following 6 groups including (1) Forest, (2) Farmland, (3) Garden-plot, (4) Built-up, (5) Water, and (6) Barren, respectively. In 1985, the first year of this study, the top three land cover classes were forest, farmland, and garden plot, which covered respectively, $62.6 \%, 28.1 \%$, and $3.7 \%$ of the land area in the Tiaoxi watershed (Table 6 and Figure 3). The forest class is mostly concentrated in the southwest mountains part of the study area; the farmland is mainly in the northern plains; the garden plot is distributed throughout the northwestern part of the watershed, in a transitional area between forest and farmland. Results show, over the past three decades, due to the urbanization process and agriculture upgrading: 1) the five urban areas (Huzhou, Changxing, Anji, Deqing, and Linan) had been expanding significantly, a large number of cultivated land and orchard were transformed into build-up land; 2) cropland and forest land were swallowed by garden-plot such as fruit trees and tea trees; 3 ) farmland loss is not only due to urban areas outward expansion but also to the transformation of rural arable land. The distribution of various land use classes for the years 1985, 1990, 1995, 2000, 2005, 2010, and 2015 and their change scenarios between different time frames are shown in Table 7 and Figure 4, respectively.

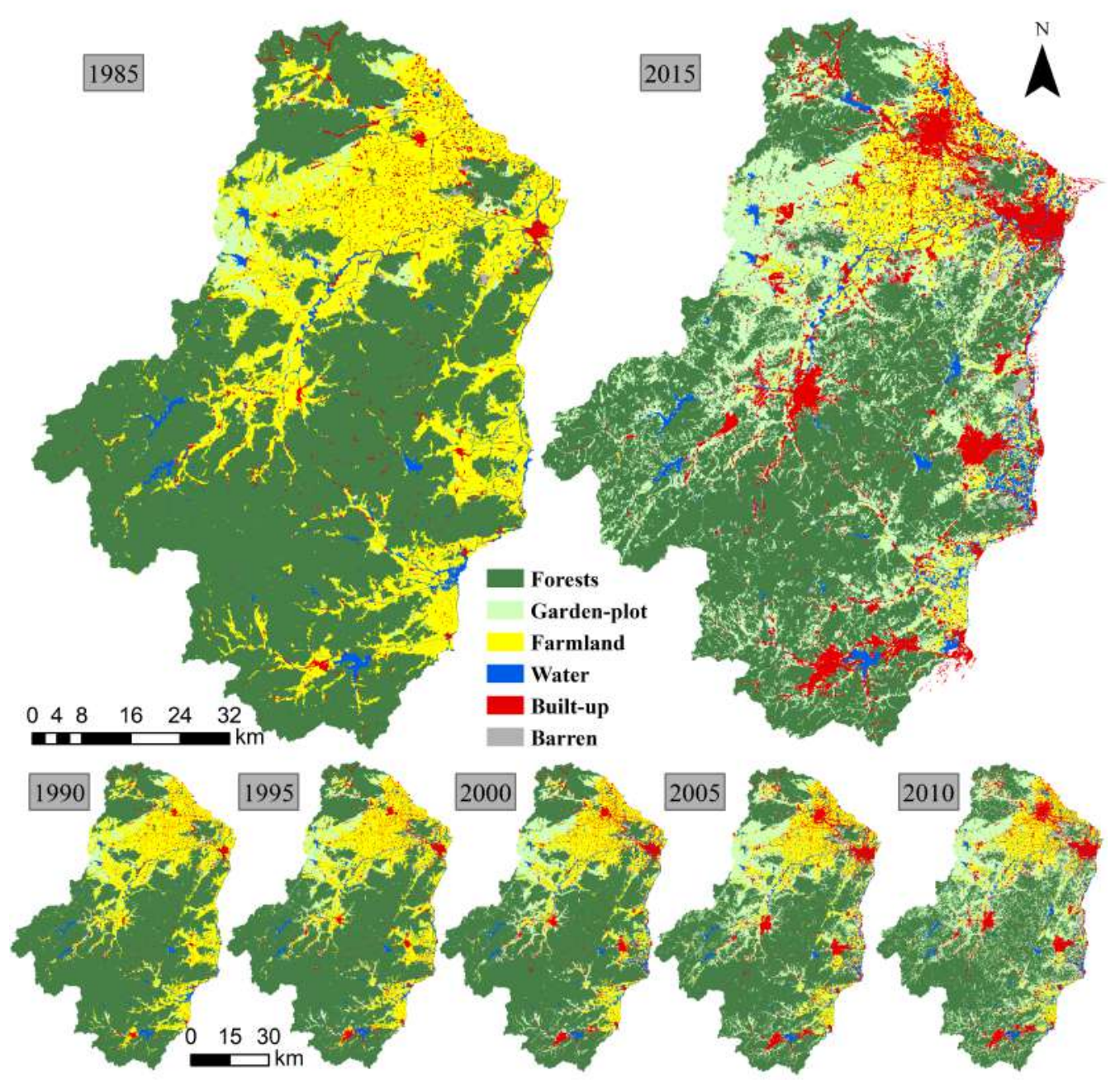

Figure 3. Segmentation parameters and main usage of each level (Land use and land cover classification in Tiaoxi watershed during 1985 and 2015). 


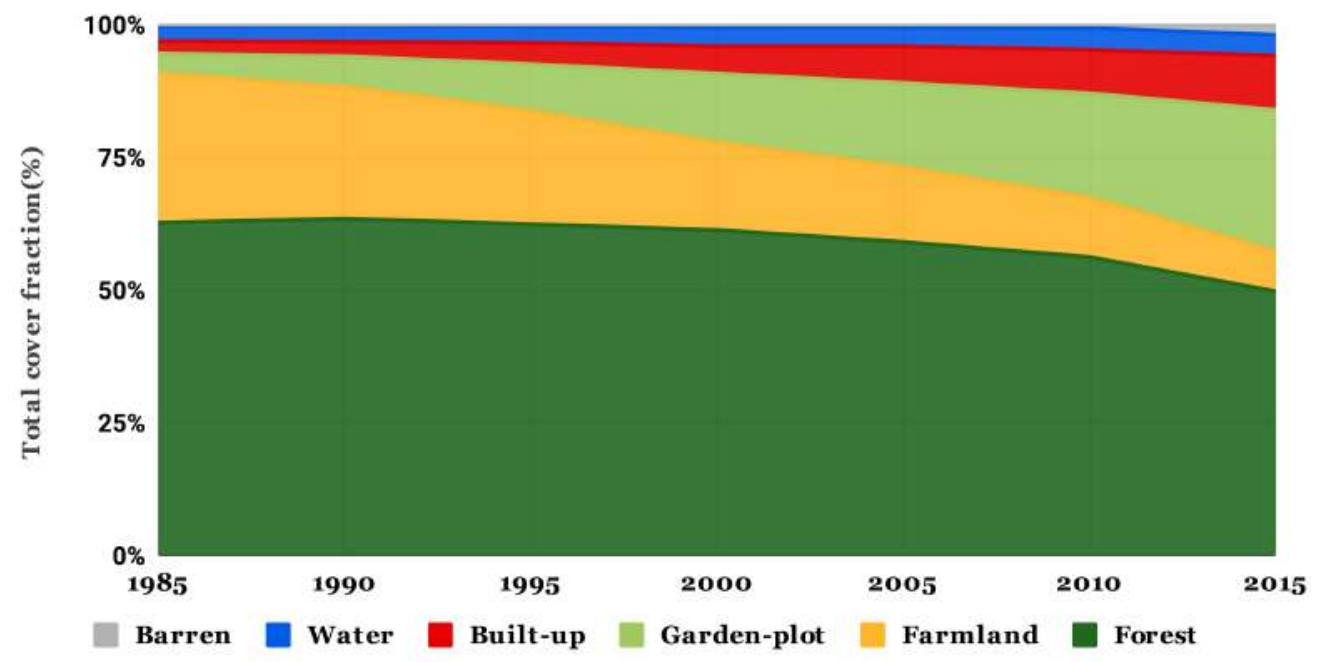

Figure 4. Segmentation parameters and main usage of each level Temporal dynamics of the net land cover changes in Tiaoxi watershed between 1985 and 2015 based on remote sensing images.

Table 6. Land use and land cover changes in Tiaoxi watershed from 1985 to 2015.

\begin{tabular}{lllllllll}
\hline Classification & & $\mathbf{1 9 8 5}$ & $\mathbf{1 9 9 0}$ & $\mathbf{1 9 9 5}$ & $\mathbf{2 0 0 0}$ & $\mathbf{2 0 0 5}$ & $\mathbf{2 0 1 0}$ & $\mathbf{2 0 1 5}$ \\
\hline \multirow{2}{*}{ Forest } & Area $\left(\mathrm{km}^{2}\right)$ & 3658.9 & 3703.1 & 3642.2 & 3578.3 & 3446.0 & 3280.0 & 2903.9 \\
& Percentage (\%) & 62.6 & 63.4 & 62.3 & 61.2 & 59.0 & 56.1 & 49.7 \\
Farmland & Area $\left(\mathrm{km}^{2}\right)$ & 1642.5 & 1451.5 & 1244.7 & 962.5 & 821.8 & 650.9 & 439.8 \\
& Percentage (\%) & 28.1 & 24.8 & 21.3 & 16.5 & 14.1 & 11.1 & 7.5 \\
Garden-plot & Area $\left(\mathrm{km}^{2}\right)$ & 218.7 & 335.0 & 516.0 & 758.6 & 929.0 & 1150.0 & 1555.1 \\
& Percentage (\%) & 3.7 & 5.7 & 8.8 & 13.0 & 15.9 & 19.7 & 26.6 \\
Built-up & Area $\left(\mathrm{km}^{2}\right)$ & 138.6 & 161.9 & 236.8 & 302.8 & 405.3 & 480.4 & 598.1 \\
\multirow{3}{*}{ Water } & Percentage (\%) & 2.4 & 2.8 & 4.1 & 5.2 & 6.9 & 8.2 & 10.2 \\
\multirow{3}{*}{ Barren } & Area $\left(\mathrm{km}^{2}\right)$ & 168.5 & 180 & 181.4 & 208.8 & 210.1 & 240.9 & 228.6 \\
& Percentage (\%) & 2.9 & 3.1 & 3.1 & 3.6 & 3.6 & 4.1 & 3.9 \\
& Area $\left(\mathrm{km}^{2}\right)$ & 14.1 & 9.9 & 20.2 & 30.4 & 29.0 & 39.1 & 115.8 \\
& Percentage (\%) & 0.2 & 0.2 & 0.3 & 0.5 & 0.5 & 0.7 & 2.0 \\
\hline
\end{tabular}


Table 7. Absolute loss $\left(\mathrm{km}^{2}\right)$, absolute gain $\left(\mathrm{km}^{2}\right)$, net change $\left(\mathrm{km}^{2}\right)$, and annual change rate $\left(\mathrm{km}^{2} \cdot \mathrm{y}^{-1}\right)$ for all land cover types for different periods between 1985 and 2015.

\begin{tabular}{|c|c|c|c|c|c|c|c|c|}
\hline & & $\begin{array}{l}1985- \\
1990\end{array}$ & $\begin{array}{l}1990- \\
1995\end{array}$ & $\begin{array}{l}1995- \\
2000\end{array}$ & $\begin{array}{l}2000- \\
2005\end{array}$ & $\begin{array}{l}2005- \\
2010\end{array}$ & $\begin{array}{l}2010- \\
2015\end{array}$ & $\begin{array}{l}\text { annual } \\
\text { change } \\
\text { rate }\end{array}$ \\
\hline \multirow[t]{5}{*}{ Forest } & gain & 103.0 & 40.1 & 28.6 & 80.7 & 30.4 & 5.0 & \\
\hline & loss & 58.9 & 100.6 & 92.7 & 211.7 & 197.2 & 381.0 & \\
\hline & gross & 161.9 & 140.7 & 121.3 & 292.4 & 227.5 & 386.0 & 44.3 \\
\hline & net & 44.2 & -60.4 & -64.1 & -131.0 & -166.8 & -376.1 & -25.1 \\
\hline & rate & 8.8 & -12.1 & -12.8 & -26.2 & -33.4 & -75.2 & \\
\hline \multirow[t]{5}{*}{ Farmland } & gain & 76.9 & 49.9 & 31.7 & 73.2 & 2.6 & 0.0 & \\
\hline & loss & 267.8 & 256.7 & 313.9 & 213.9 & 172.9 & 211.6 & \\
\hline & gross & 344.7 & 306.6 & 345.6 & 287.1 & 175.5 & 211.6 & 55.7 \\
\hline & net & -190.8 & -206.8 & -282.2 & -140.6 & -170.2 & -211.6 & -40.1 \\
\hline & rate & -38.2 & -41.4 & -56.4 & -28.1 & -34.0 & -42.3 & \\
\hline \multirow[t]{5}{*}{ Garden-plot } & gain & 140.1 & 205.5 & 254.6 & 277.1 & 274.8 & 522.3 & \\
\hline & loss & 24.3 & 24.4 & 12.0 & 108.0 & 52.7 & 116.6 & \\
\hline & gross & 164.5 & 230.0 & 266.6 & 385.1 & 327.5 & 638.9 & 67.1 \\
\hline & net & 115.8 & 181.1 & 242.6 & 169.1 & 222.1 & 405.7 & 44.5 \\
\hline & rate & 23.2 & 36.2 & 48.5 & 33.8 & 44.4 & 81.1 & \\
\hline \multirow[t]{5}{*}{ Built-up } & gain & 25.6 & 86.3 & 74.4 & 103.4 & 82.4 & 129.2 & \\
\hline & loss & 2.3 & 11.8 & 8.4 & 0.8 & 7.9 & 11.6 & \\
\hline & gross & 27.9 & 98.1 & 82.8 & 104.2 & 90.3 & 140.9 & 18.1 \\
\hline & net & 23.3 & 74.5 & 66.0 & 102.6 & 74.4 & 117.6 & 15.3 \\
\hline & rate & 4.7 & 14.9 & 13.2 & 20.5 & 14.9 & 23.5 & \\
\hline \multirow[t]{5}{*}{ Water } & gain & 42.7 & 43.0 & 62.9 & 49.9 & 45.2 & 27.3 & \\
\hline & loss & 31.1 & 41.6 & 35.3 & 48.7 & 14.7 & 39.0 & \\
\hline & gross & 73.8 & 84.6 & 98.2 & 98.5 & 59.9 & 66.3 & 16.0 \\
\hline & net & 11.6 & 1.4 & 27.5 & 1.2 & 30.5 & -11.7 & 2.0 \\
\hline & rate & 2.3 & 0.3 & 5.5 & 0.2 & 6.1 & -2.3 & \\
\hline \multirow[t]{5}{*}{ Barren } & gain & 2.5 & 12.9 & 19.2 & 15.9 & 13.1 & 79.3 & \\
\hline & loss & 6.6 & 2.7 & 9.1 & 17.2 & 3.1 & 3.1 & \\
\hline & gross & 9.1 & 15.6 & 28.3 & 33.0 & 16.3 & 82.4 & 6.2 \\
\hline & net & -4.1 & 10.2 & 10.1 & -1.3 & 10.0 & 76.1 & 3.4 \\
\hline & rate & -0.8 & 2.0 & 2.0 & -0.3 & 2.0 & 15.2 & \\
\hline
\end{tabular}

Forest was swallowed by farmland and garden-plot in the first five years (Figure $5 \mathrm{~A})$, With the promulgation and implementation of relevant laws, the rate of conversion of forest land to farmland has been effectively suppressed. However, the law does not prohibit the conversion of forest land into the garden-plot. As a result, a large amount of forest land has been transformed into the garden-plot under the demand for economic benefits (Figure $5 \mathrm{~B} \sim \mathrm{F}$ ). Even more worrying is that the rate of decrease is increasing.

Farmland net loss $1202.3 \mathrm{~km}^{2}$ from 1985 to 2015 , the area ratio fell from $28.1 \%$ to $7.5 \%$, which means nearly three-quarters of the arable land has been lost. Farmland was swallowed by urban areas expanding outside and garden-plot. The policy of returning farmland to forests has converted much illegal farmland into forest land and garden-plot.

In contrast, the garden-plot area increased seven-fold, from $218.7 \mathrm{~km}^{2}$ to $1,555 \mathrm{~km}^{2}$. The first 15 years (1985 2000) of the expansion of the garden-plot was transformed from farmland (Figure 5A, B and C), and the last 15 years (2001 2015) from the forest (Figure $5 \mathrm{D}, \mathrm{E}$ and F).

The build-up land area quadrupled from $138.6 \mathrm{~km}^{2}$ to $598.1 \mathrm{~km}^{2}$ over 30 years and grew by $15.3 \mathrm{~km}^{2}$ per year, increasing at an average annual rate of $9.55 \%$. At the same time, the urban population increased from 0.22 million to 1.20 million. The population density was 42.5 persons per hectare in 2015, decreasing at an average annual rate of 
$-5.2 \%$ since 1985 . Build-up land area extension rate is more than $20 \mathrm{~km}^{2}$ per year in the period of 2000 2005 and 2010 2015, the rate of growth has slowed in 20052010 because of the restrictions imposed by national policies on urban development [43]. The first 20 years (1985 2005) of the expansion of the build-up were from farmland (Figure 5A, B, C, and D), and the last 10 years (2005 2015) from the garden-plot (Figure 5E and F).

Due to the construction of reservoirs and the popularity of fishponds, the area of water has been increasing from $168.5 \mathrm{~km}^{2}$ to $228.6 \mathrm{~km}^{2}$ during 19852015 , which means increased by $34.5 \%$. Over the past three decades, the increase in water area has mainly resulted from the transformation of farmland (Figure 5).
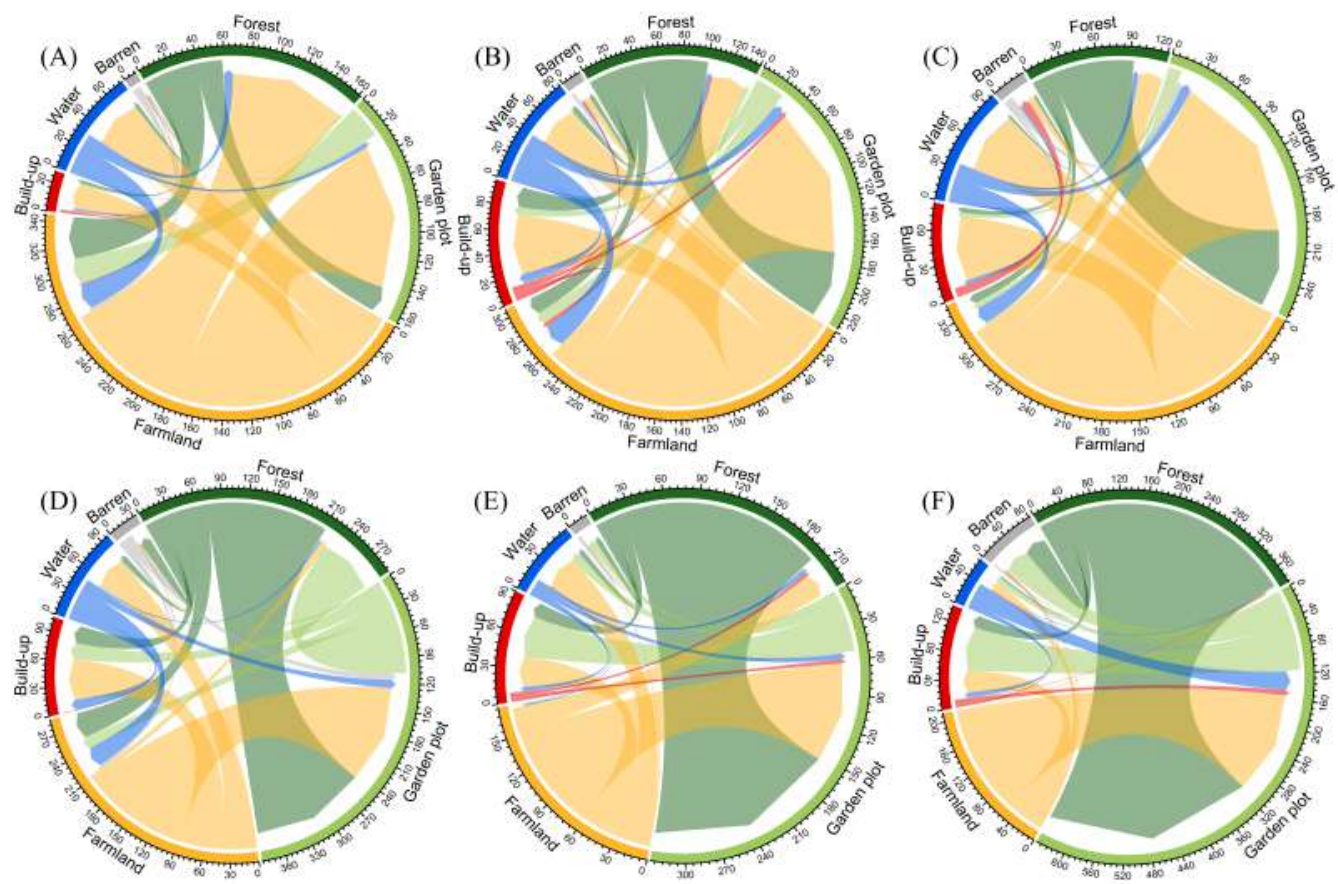

Figure 5. Land use and land cover changes in the Tiaoxi watershed between 1985 to 2015. (The direction of the arrows in the chord diagram indicates a change from the original land cover class to a new land cover class. The size of the arrows represents the land use and land cover change area).

\subsection{Spatial distribution of LULC changes}

The spatial analysis distinguished the same six time periods as found in the temporal analysis. $1.5 \times 1.5 \mathrm{~km}$ fishing nets were constructed by ArcGIS 10.5 to divide the study area into 2761 units. The intensity of LULC changes for build-up, garden-plot, farmland, and forest was calculated (Figure 6). In addition to urban expansion, the loss of farmland and the expansion of garden-plot are the main manifestations of LULC changes in the Tiaoxi watershed. At the early stages of Chinese economic reform, urban and rural development was slow, only a few scattered areas had been converted to build-up (Figure 6A). The period of housing commercialization also coincided with a period of rapid urbanization in the Tiaoxi watershed. During this period, the five central cities continued to expand (Figure 6B, C, and D). As the country put forward the new rural construction policies in 2005, the speed of rural construction is surging, The conversion of building land takes place in the vast area of the Tiaoxi watershed (Figure $6 \mathrm{E}$ and F). From 1985 to 2000, the garden-plot cover fraction increased in the northwest mountainous region (Figure 6G, H, and I). The reclamation for garden-plot speed was significantly limited in the northwest region due to the administrative restrictions of the government in the first decade of the new millennium, at the same time, seedlings were planted in the eastern part of the watershed (Figure 6J and K). From 2010 to 2015, the garden-plot cover fraction increased all over the watershed (Figure 6L). In the first two 
time periods, between 1985 and 1995, the areas of farmland decreased by $11.6 \%$, a change that was largely confined to the northwest and southern mountainous region (Figure $6 \mathrm{M}$ and N). Between 1995 and 2015, the loss of farmland was concentrated around cities such as Changxing, Huzhou, Anji, Deqing, Linan, and Yuhang (Figure 6O, P, Q, and $\mathrm{R})$. In comparison with the total forest area $(62.6 \%)$, the net change in forest cover was relatively small (12.9\%), but the spatial dynamic was considerable. In the first period, the forest area slightly increased at a speed of $0.24 \%$ per year distributed evenly throughout the watershed (Figure $6 \mathrm{~S}$ ). In the second and the third period, the forest area began to lose at a slight speed of $-0.33 \%$ and $-0.35 \%$ per year (Figure $6 \mathrm{~T}$ and U). Since the beginning of the new millennium, the loss of forests in suburban areas has accelerated (Figure 6V). As a result of the implementation of the policy of returning farmland to forests, some areas of forest area recovery (Figure 6V and W). In the last period, plenty of forest land has been converted into economic crops including tea plantations and fruit trees (Figure 6X).

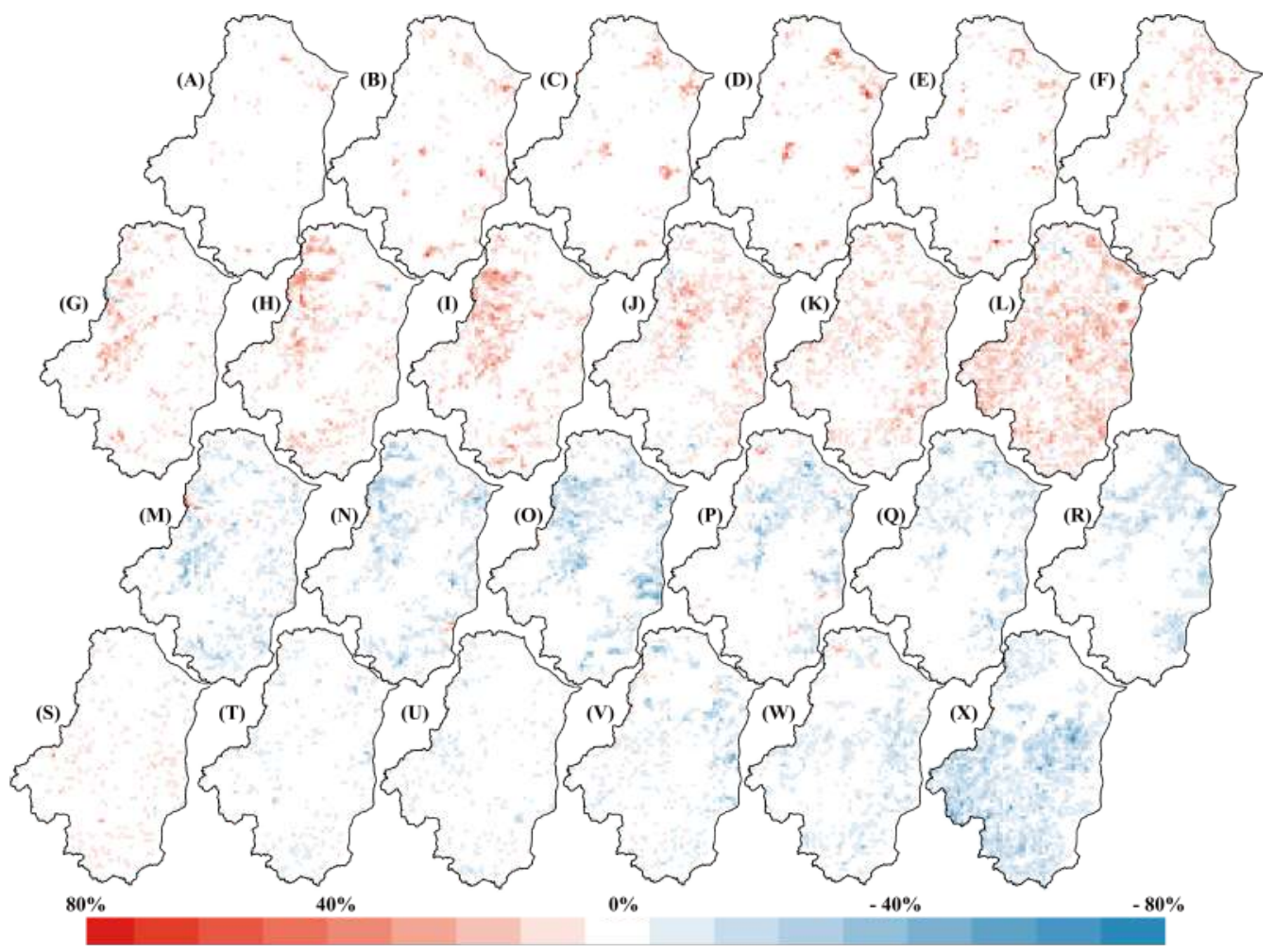

Figure 6. Spatial distribution land cover changes for Build-up(A to F), Garden plot (G to L), Farmland (M to R), and Forest ( $\mathrm{S}$ to X) in Tiaoxi watershed for six periods:1985 1990 (A, G, M, S), 1990 1995 (B, H, N, I), 1995 2000 (C, I, O, U). 2000 2005 (D, J, P, V), 2005 2010(E, K, Q, W), and 2010 2015 (F, L, R, X). Blue indicates a decreasing fraction and red an increasing fraction.).

\section{Discussion}

The causes of LULC changes in the Tiaoxi watershed included urbanization, regional population growth, and agriculture efficiency improvement.

\subsection{Urbanization}

China's rapid urbanization has attracted international attention. The level of urbanization in the Tiaoxi watershed increased from $10.3 \%$ in 1978 to $44.9 \%$ in 2015 . It's a real challenge to soil protection and food security. During the past four decades, China has experienced the largest and fast industrialization and urbanization in the world. Tiaoxi watershed LULC changes are the symbols of China's urbanization. Urban expansion in the area has led to the conversion of farmland and forest land into the impermeable surface. However, the social structure of population aging and the migration of younger 
people to cities has caused rural development limitations. In the future, the expansion rate of small and medium-sized towns will be further reduced or even reversed.

\subsection{Regional population growth}

Development and migration are related. Economy growth in China is highly uneven at both provincial and prefectural levels. The study area is one of the most economically developed regions in China, attracting most immigrants in past decades. Expanding population needs urban expansion to provide basic services, infrastructure, and housing. Forestland and farmland around the old city face increasing pressures from growing populations and urban expansion. Regional competition ability will be an important driving force for land use transformation in this area.

\subsection{Agriculture efficiency improvement}

Before 1978, when China adopted a planned economy, agricultural productivity was low, the product category was unitary, Trade-in grain and other agricultural products were strictly controlled or prohibited. With the opening of the market and the liberalization of the ban on trade in agricultural products, agricultural land in economically developed areas is gradually transformed into land for cash crops, which will produce higher economic value. Land scarcity changes land-labor ratios, driving up the intensity of cultivation and where possible, shifting production toward the market and to higher-value products. The threat of a food crisis forced the government to implement the Dynamic Balance of Total Farmland Area (DBTFA) policy in 1998, with the overall goal of maintaining at least 120 million arable hectares by 2020. The development of science and technology has brought about an increase in grain production. The demand for farmland is decreasing. For these reasons, the total area of arable land will remain unchanged or decrease very slowly in the future.

\section{Conclusions}

We developed a method for remote-sensing LULC changes detection that uses multi-temporal high-resolution imagery. The method applies an Object-based approach using geostatistical features obtained from four seasons images as input data to support vector machine (SVM) algorithm. The accuracy of the classification was consistently high. The accuracy of Land classification is crucial to identify the characteristics of the land and make reasonable use of land resources. LULC changed significantly from 1985 to 2015 due to intensive human activities, proved by dramatic construction of land and garden-plot expansion and large shrinkage of forest land and farmland. The areas with the greatest intensity of LULC changes are concentrated in the surrounding areas of cities and towns. LULC changes in the Tiaoxi watershed are a microcosm of China's social development and urbanization in the past decades. Author Contributions:

Conceptualization, D.L. and J.W.; methodology, D.L.; software, R.J.; validation, D.L., J.G. and R.J.; formal analysis, D.L.; investigation, J.W.; resources, J.W.; data curation, D.L.; writingoriginal draft preparation, D.L.; writing—review and editing, D.L. and J.w.; visualization, D.L .; supervision, J.W.; project administration, D.L.; funding acquisition, J.W. All authors have read and agreed to the published version of the manuscript.

Funding: This research was supported by the National Key Research and Development Program of China (Grant No. 2017YFC1405402).

Institutional Review Board Statement: Not applicable

Informed Consent Statement: Not applicable

Acknowledgments:

Conflicts of Interest: The funders had no role in the design of the study; in the collection, analyses, or interpretation of data; in the writing of the manuscript, or in the decision to publish the results 


\section{References}

1. Zhang, F.; Tiyip, T.; Kung, H.; Johnson, V.C.; Maimaitiyiming, M.; Zhou, M.; Wang, J. Dynamics of land surface temperature (LST) in response to land use and land cover (LULC) changes in the Weigan and Kuqa river oasis, Xinjiang, China. Arabian Journal of Geosciences 2016, 9, 499. Number: 7, doi:10.1007/s12517-016-2521-8.

2. Lambin, E.F.; Meyfroidt, P. Global land use change, economic globalization, and the looming land scarcity. Proceedings of the National Academy of Sciences 2011, 108, 3465-3472. Number: 9, doi:10.1073/pnas.1100480108.

3. Lambin, E.F.; Turner, B.; Geist, H.J.; Agbola, S.B.; Angelsen, A.; Bruce, J.W.; Coomes, O.T.; Dirzo, R.; Fischer, G.; Folke, C.; George, P.; Homewood, K.; Imbernon, J.; Leemans, R.; Li, X.; Moran, E.F.; Mortimore, M.; Ramakrishnan, P.; Richards, J.F.; Sk \aanes, H.; Steffen, W.; Stone, G.D.; Svedin, U.; Veldkamp, T.A.; Vogel, C.; Xu, J. The causes of land-use and land-cover change: moving beyond the myths. Global Environmental Change 2001, 11, 261-269. Number: 4, doi:10.1016/S0959-3780(01)00007-3.

4. Martin, S.L.; Hayes, D.B.; Kendall, A.D.; Hyndman, D.W. The land-use legacy effect: Towards a mechanistic understanding of time-lagged water quality responses to land use/cover. Science of The Total Environment 2017, 579, 1794-1803. doi:10.1016/j.scitotenv.2016.11.158.

5. Fassnacht, F.E.; Latifi, H.; Stereńczak, K.; Modzelewska, A.; Lefsky, M.; Waser, L.T.; Straub, C.; Ghosh, A. Review of studies on tree species classification from remotely sensed data. Remote Sensing of Environment 2016, 186, 64-87. doi:10.1016/j.rse.2016.08.013.

6. Pu, R.; Landry, S.; Yu, Q. Assessing the potential of multi-seasonal high resolution Pléiades satellite imagery for mapping urban tree species. International Journal of Applied Earth Observation and Geoinformation 2018, 71, 144-158. doi:10.1016/j.jag.2018.05.005.

7. Gudex-Cross, D.; Pontius, J.; Adams, A. Enhanced forest cover mapping using spectral unmixing and object-based classification of multi-temporal Landsat imagery. Remote Sensing of Environment 2017, 196, 193-204. doi:10.1016/j.rse.2017.05.006.

8. Higginbottom, T.P.; Symeonakis, E.; Meyer, H.; van der Linden, S. Mapping fractional woody cover in semi-arid savannahs using multi-seasonal composites from Landsat data. ISPRS Journal of Photogrammetry and Remote Sensing 2018, 139, 88-102. doi:10.1016/j.isprsjprs.2018.02.010.

9. Veloso, A.; Mermoz, S.; Bouvet, A.; Le Toan, T.; Planells, M.; Dejoux, J.F.; Ceschia, E. Understanding the temporal behavior of crops using Sentinel-1 and Sentinel-2-like data for agricultural applications. Remote Sensing of Environment 2017, 199, 415-426. doi:10.1016/j.rse.2017.07.015.

10. Cai, Y.; Guan, K.; Peng, J.; Wang, S.; Seifert, C.; Wardlow, B.; Li, Z. A high-performance and in-season classification system of field-level crop types using time-series Landsat data and a machine learning approach. Remote Sensing of Environment 2018, 210, 35-47. doi:10.1016/j.rse.2018.02.045.

11. Shekede, M.D.; Murwira, A.; Masocha, M. Wavelet-based detection of bush encroachment in a savanna using multi-temporal aerial photographs and satellite imagery. International Journal of Applied Earth Observation and Geoinformation 2015, 35, $209-216$. doi:10.1016/j.jag.2014.08.019.

12. Poulin, B.; Davranche, A.; Lefebvre, G. Ecological assessment of Phragmites australis wetlands using multi-season SPOT-5 scenes. Remote Sensing of Environment 2010, 114, 1602-1609. Number: 7, doi:10.1016/j.rse.2010.02.014.

13. Löw, F.; Conrad, C.; Michel, U. Decision fusion and non-parametric classifiers for land use mapping using multi-temporal RapidEye data. ISPRS Journal of Photogrammetry and Remote Sensing 2015, 108, 191-204. doi:10.1016/j.isprsjprs.2015.07.001.

14. Griffiths, P.; Nendel, C.; Hostert, P. Intra-annual reflectance composites from Sentinel-2 and Landsat for national-scale crop and land cover mapping. Remote Sensing of Environment 2019, 220, 135-151. doi:10.1016/j.rse.2018.10.031.

15. Morchhale, S.; Pauca, V.P.; Plemmons, R.J.; Torgersen, T.C. Classification of pixel-level fused hyperspectral and lidar data using deep convolutional neural networks. 2016 8th Workshop on Hyperspectral Image and Signal Processing: Evolution in Remote Sensing (WHISPERS). IEEE, 2016, pp. 1-5. doi:10.1109/WHISPERS.2016.8071715.

16. Benedetti, P.; Ienco, D.; Gaetano, R.; Ose, K.; Pensa, R.G.; Dupuy, S. M^3Fusion: A Deep Learning Architecture for Multiscale Multimodal Multitemporal Satellite Data Fusion. IEEE Journal of Selected Topics in Applied Earth Observations and Remote Sensing 2018, 11, 4939-4949. Number: 12, doi:10.1109/JSTARS.2018.2876357.

17. Nogueira, K.; dos Santos, J.A.; Menini, N.; Silva, T.S.F.; Morellato, L.P.C.; Torres, R.d.S. Spatio-Temporal Vegetation Pixel Classification by Using Convolutional Networks. IEEE Geoscience and Remote Sensing Letters 2019, 16, 1665-1669. Number: 10, doi:10.1109/LGRS.2019.2903194.

18. Firozjaei, M.K.; Kiavarz, M.; Alavipanah, S.K.; Lakes, T.; Qureshi, S. Monitoring and forecasting heat island intensity through multi-temporal image analysis and cellular automata-Markov chain modelling: A case of Babol city, Iran. Ecological Indicators 2018, 91, 155-170. doi:10.1016/j.ecolind.2018.03.052.

19. Aplin, P.; Smith, G.M. Introduction to object-based landscape analysis. International Journal of Geographical Information Science 2011, 25, 869-875. Number: 6, doi:10.1080/13658816.2011.566570.

20. Bolte, S.; Cordelières, F.P. A guided tour into subcellular colocalization analysis in light microscopy. Journal of Microscopy 2006, 224, 213-232. Number: 3, doi:10.1111/j.1365-2818.2006.01706.x.

21. Yu, Q.; Gong, P.; Clinton, N.; Biging, G.; Kelly, M.; Schirokauer, D. Object-based Detailed Vegetation Classification with Airborne High Spatial Resolution Remote Sensing Imagery. Photogrammetric Engineering E Remote Sensing 2006, 72, 799-811. Number: 7, doi:10.14358/PERS.72.7.799.

22. Liu, H.; Wang, L.; Sherman, D.; Gao, Y.; Wu, Q. An object-based conceptual framework and computational method for representing and analyzing coastal morphological changes. International Journal of Geographical Information Science 2010, 24, 1015-1041. Number: 7, doi:10.1080/13658810903270569. 
23. Radoux, J.; Bogaert, P.; Fasbender, D.; Defourny, P. Thematic accuracy assessment of geographic object-based image classification. International Journal of Geographical Information Science 2011, 25, 895-911. Number: 6, doi:10.1080/13658816.2010.498378.

24. Ma, L.; Fu, T.; Li, M. Active learning for object-based image classification using predefined training objects. International Journal of Remote Sensing 2018, 39, 2746-2765. Number: 9, doi:10.1080/01431161.2018.1430398.

25. Berhane, T.M.; Costa, H.; Lane, C.R.; Anenkhonov, O.A.; Chepinoga, V.V.; Autrey, B.C. The Influence of Region of Interest Heterogeneity on Classification Accuracy in Wetland Systems. Remote Sensing 2019, 11, 551. Number: 5, doi:10.3390/rs11050551.

26. Souza-Filho, P.W.M.; Giannini, T.C.; Jaffé, R.; Giulietti, A.M.; Santos, D.C.; Nascimento, W.R.; Guimarães, J.T.F.; Costa, M.F.; Imperatriz-Fonseca, V.L.; Siqueira, J.O. Mapping and quantification of ferruginous outcrop savannas in the Brazilian Amazon: A challenge for biodiversity conservation. PLOS ONE 2019, 14, e0211095. Number: 1, doi:10.1371/journal.pone.0211095.

27. Li, Z.; Sun, Z.; Tian, Y.; Zhong, J.; Yang, W. Impact of Land Use/Cover Change on Yangtze River Delta Urban Agglomeration Ecosystem Services Value: Temporal-Spatial Patterns and Cold/Hot Spots Ecosystem Services Value Change Brought by Urbanization. International Journal of Environmental Research and Public Health 2019, 16, 123. Number: 1, doi:10.3390/ijerph16010123.

28. Meng, L.; Sun, Y.; Zhao, S. Comparing the spatial and temporal dynamics of urban expansion in Guangzhou and Shenzhen from 1975 to 2015: A case study of pioneer cities in China's rapid urbanization. Land Use Policy 2020, $97,104753$. doi:https:/ /doi.org/10.1016/j.landusepol.2020.104753.

29. Vadde, K.K.; Wang, J.; Cao, L.; Yuan, T.; McCarthy, A.J.; Sekar, R. Assessment of Water Quality and Identification of Pollution Risk Locations in Tiaoxi River (Taihu Watershed), China. Water 2018, 10. doi:10.3390/w10020183.

30. Chowdhury, M.; Hasan, M.E.; Abdullah-Al-Mamun, M. Land use/land cover change assessment of Halda watershed using remote sensing and GIS. The Egyptian Journal of Remote Sensing and Space Science 2020, 23, 63-75. Number: 1, doi:10.1016/j.ejrs.2018.11.003.

31. Orsini, S. Explaining land management decisions to understand local landscape functions and change. Some insights from Tuscany. Local Environment 2013, 18, 934-949. Number: 8, doi:10.1080/13549839.2012.748726.

32. Li, D.; Christakos, G.; Ding, X.; Wu, J. Adequacy of TRMM satellite rainfall data in driving the SWAT modeling of Tiaoxi catchment (Taihu lake basin, China). Journal of Hydrology 2018, 556, 1139-1152. doi:10.1016/j.jhydrol.2017.01.006.

33. Xiao, R.; Jiang, D.; Christakos, G.; Fei, X.; Wu, J. Soil Landscape Pattern Changes in Response to Rural Anthropogenic Activity across Tiaoxi Watershed, China. PLOS ONE 2016, 11, e0166224. Number: 11 Publisher: Public Library of Science, doi:10.1371/journal.pone.0166224.

34. Sibanda, M.; Murwira, A. The use of multi-temporal MODIS images with ground data to distinguish cotton from maize and sorghum fields in smallholder agricultural landscapes of Southern Africa. International Journal of Remote Sensing 2012, 33, 4841-4855. Number: 16, doi:10.1080/01431161.2011.635715.

35. Wilson, N.R.; Norman, L.M. Analysis of vegetation recovery surrounding a restored wetland using the normalized difference infrared index (NDII) and normalized difference vegetation index (NDVI). International Journal of Remote Sensing 2018, 39, 32433274. Number: 10, doi:10.1080/01431161.2018.1437297.

36. Guha, S.; Govil, H.; Dey, A.; Gill, N. Analytical study of land surface temperature with NDVI and NDBI using Landsat 8 OLI and TIRS data in Florence and Naples city, Italy. European Journal of Remote Sensing 2018, 51, 667-678. Number: 1 Publisher: Taylor \& Francis_eprint: https://doi.org/10.1080/22797254.2018.1474494, doi:10.1080/22797254.2018.1474494.

37. Liu, Q.; Song, H.; Liu, G.; Huang, C.; Li, H. Evaluating the Potential of Multi-Seasonal CBERS-04 Imagery for Mapping the Quasi-Circular Vegetation Patches in the Yellow River Delta Using Random Forest. Remote Sensing 2019, 11, 1216. Number: 10, doi:10.3390/rs11101216.

38. Torres-Sánchez, J.; López-Granados, F.; Peña, J. An automatic object-based method for optimal thresholding in UAV images: Application for vegetation detection in herbaceous crops. Computers and Electronics in Agriculture 2015, $114,43-52$. doi:10.1016/j.compag.2015.03.019.

39. Zhu, Z.; Fu, Y.; Woodcock, C.E.; Olofsson, P.; Vogelmann, J.E.; Holden, C.; Wang, M.; Dai, S.; Yu, Y. Including land cover change in analysis of greenness trends using all available Landsat 5, 7, and 8 images: A case study from Guangzhou, China (2000-2014). Remote Sensing of Environment 2016, 185, 243-257. doi:10.1016/j.rse.2016.03.036.

40. Liu, X.; Hu, G.; Chen, Y.; Li, X.; Xu, X.; Li, S.; Pei, F.; Wang, S. High-resolution multi-temporal mapping of global urban land using Landsat images based on the Google Earth Engine Platform. Remote Sensing of Environment 2018, 209, 227-239. doi:10.1016/j.rse.2018.02.055.

41. Stehman, S.V.; Hansen, M.C.; Broich, M.; Potapov, P.V. Adapting a global stratified random sample for regional estimation of forest cover change derived from satellite imagery. Remote Sensing of Environment 2011, 115, 650-658. Number: 2, doi:10.1016/j.rse.2010.10.009.

42. Huang, Z.; Lees, B. Assessing a single classification accuracy measure to deal with the imprecision of location and class: Fuzzy weighted kappa versus kappa. Journal of Spatial Science 2007, 52, 1-12. Number: 1, doi:10.1080/14498596.2007.9635096.

43. Yang, T.; Jiang, S.; Oliffe, J.L.; Feng, X.; Zheng, J. Environmental Smoking Restrictions and Light Cigarette Adoption Among Chinese Urban Smokers. Prevention Science 2015, 16, 801-810. Number: 6, doi:10.1007/s11121-014-0541-8. 